\title{
Provenance and depositional environments of Quaternary sediments from the western North Sea Basin
}

\author{
Davies, B.J. ${ }^{1 *}$, Roberts, D.H. ${ }^{1}$, Bridgland, D.R. ${ }^{1}$, Ó Cofaigh, C. ${ }^{1}$, and Riding, J.B . \\ ${ }^{1}$ Department of Geography, Durham University, Science Laboratories, South Road, Durham DH1 3LE \\ ${ }^{2}$ British Geological Survey, Kingsley Dunham Centre, Keyworth, Nottingham NG12 5GG \\ *bethandavies@dunelm.org.uk.
}

\begin{abstract}
The majority of the data on Quaternary sediments from the North Sea Basin is seismostratigraphical, with little quantitative provenance or process research having been undertaken. We analysed the Elsterian (MIS 12) Swarte Bank Formation, the Saalian (MIS 6/8) Fisher Formation, and the Late Weichselian (MIS 2) Bolders Bank Formation in order to determine genesis and provenance. Micromorphological, heavy mineral, petrological, geochemical and palynological analyses were undertaken. The Swarte Bank Formation is interpreted as a subglacial till that contains Jurassic and Triassic palynofloras from the Moray Forth, and Eocene and Late Cretaceous palynofloras from the northeastern North Sea. It also contains a metamorphic suite of heavy minerals indicative of the Scottish Highlands. The Fisher Formation was sampled from the northern and central North Sea. In the north, it is interpreted as a subglacial till, with glaciomarine sediments cropping out further south. These sediments exhibit a provenance signature consistent with the Midland Valley of Scotland and the Eocene of the North Sea Basin. Heavy mineral analysis suggests a derivation from the Grampian Highlands and northeast Scotland. The Late Weichselian (Dimlington Stadial) Bolders Bank Formation is interpreted as a subglacial till that contains Silurian palynomorphs from the Midland Valley of Scotland, Jurassic and Carboniferous palynofloras from northern Britain, and a metamorphic heavy mineral suite indicative of material derived from the Grampian Highlands, the Dalradian, and NE Scotland. These data demonstrate that there was repeated glaciation of the North Sea Basin during the Middle and Late Pleistocene, with ice sheets originating in northern Scotland.
\end{abstract}

\section{Introduction}

The North Sea Basin is a subsiding post-Palaeozoic multi-stage rift zone within the northwest European craton. Rapid subsidence during the Pliocene and Pleistocene resulted in an extensive succession of Quaternary sediments, thickening towards the east. Towards the eastern British coastline, the Quaternary sediments gradually thin, and boreholes near 
the coastline prove bedrock at the seabed (Cameron et al., 1992). As a sediment sink, the North Sea has the potential to provide detailed information regarding Quaternary glacialinterglacial cycles. However land-sea correlations are currently tentative and stratigraphical control is poor, because the offshore successions are essentially based on seismostratigraphy. By contrast the coeval onshore successions are mostly subdivided lithostratigraphically and biostratigraphically, and are not mappable offshore (Cameron et al., 1992). The eastern limits of the British-Irish Ice Sheet and the western limits of the Fennoscandian Ice Sheet during the Quaternary are also poorly understood (Catt, 1991; Sejrup et al., 2009). This creates difficulties in accurately modelling their mass and flow trajectories through space and time. In addition, the North Sea would have destabilised these ice sheets and encouraged calving, thus forming a powerful barrier to these ice sheets. Investigating the sediments in the North Sea Basin, and attempting to correlate them with lithostratigraphical units and sediment-landform associations onshore in eastern England, could help to constrain and model dynamic interactions between the British and Fennoscandian ice sheets during the Quaternary.

This study used micromorphological, geochemical, palynological, and petrological techniques to reconstruct the provenance and process history of the offshore sedimentary record in the North Sea. It aims firstly to improve understanding of the process history of key formations in the North Sea, and secondly, to reconstruct the provenance signature of these units. Samples were taken from three units; the Swarte Bank, Fisher, and Bolders Bank formations, representing MIS 12 (Elsterian), MIS 6/8 (Saalian) and MIS 2 (Late Weichselian) respectively. These formations have been related to key sites in eastern England, and used to clarify onshore-offshore correlations and the Quaternary ice sheet history of the eastern margin of the British-Irish Ice Sheet. Local British/European chronostratigraphical terms are used in this study where appropriate, but 'Devensian' is presumed to be equivalent to the 'Weichselian' (MIS 4-2), and 'Anglian' coeval with the ‘Elsterian' (MIS 12) European glaciation.

\section{North Sea Stratigraphy}

\section{Middle to Upper Pleistocene sediments of the North Sea}

During the Elsterian (MIS 12), full glacial conditions led to the erosion and infilling of a major system of tunnel valleys, up to $12 \mathrm{~km}$ wide and $400 \mathrm{~m}$ deep, in the southern North Sea Basin (Cameron et al., 1987; Balson and Jeffery, 1991). These trend NNW-SSE, and are most extensively developed between $53^{\circ} \mathrm{N}$ and $54^{\circ} \mathrm{N}$, and east of $2^{\circ} \mathrm{E}$. These valleys, which have irregular thalwegs, were formed via erosion by pressurised subglacial meltwater (Balson and Jeffery, 1991; Huuse and Lykke-Andersen, 2000) and are infilled by the Swarte 
Bank Formation (Cameron et al., 1992; Gatliff et al., 1994) (Fig. 1). Scourse et al. (1998) correlated the Swarte Bank Formation with the Lowestoft Till of East Anglia, due to similar lithological properties, and interpreted it as an Elsterian subglacial till. Cameron et al. (1992) concurred with an Elsterian age, based on its stratigraphical position between the Cromerian-Complex Yarmouth Roads Formation and sediments with interglacial Hoxnian fossil assemblages (Ehlers et al., 1984).

The Fisher Formation is widely distributed north of $56^{\circ} \mathrm{N}$, and may be partly correlative with the Alkaid Member of the Yarmouth Roads Formation (Sejrup et al., 1991; Gatliff et al., 1994). It overlies the Ling Bank Formation in BGS borehole 81/34, where a major unconformity from a marine transgression is overlain by around $6 \mathrm{~m}$ of interbedded finegrained sand to stiff, dark-grey mud (Stoker et al., 1985; Andrews et al., 1990). An arctic foraminiferal fauna supports an interpretation as a glaciomarine diamicton deposited during a post-Elsterian, pre- Weichselian glaciation (Gatliff et al., 1994).

\section{The Last Glacial Maximum}

The term Last Glacial Maximum refers here to the period of global ice sheet maxima, from 30-22 calendar ka BP, peaking at 26 calendar ka BP (Peltier and Fairbanks, 2006), when the last British-Irish Ice Sheet was characterised by shelf-wide glaciation (Bradwell et al., 2008). The Dimlington and Tampen stadials occurred around 22 calendar ka BP and have been interpreted as more restricted, with the ice sheet not extending as far as Norfolk or advancing far onto the continental shelf (Sejrup et al., 1994; Bowen et al., 2002). In eastern England, the onshore limit of Dimlington ice is delineated by the Skipsea Member in Yorkshire (Catt and Penny, 1966; Rose, 1985; Evans et al., 1995; Clark et al., 2004a; Bateman et al., 2008).

Ehlers and Wingfield (1991) interpreted the incised valleys present both beneath the North Sea and inland in northern Germany as marginal subglacial meltwater channels. These tunnel valleys extend beyond the Dimlington till sheet limits, indicating that the extent of Late Weichselian ice in the North Sea was greater than that suggested by the sedimentary record. Ehlers and Wingfield (1991) argued that the Fennoscandian Ice Sheet and BritishIrish Ice Sheet may have coalesced in the North Sea, with extensive glaciation in the central and southern North Sea Basin. Sejrup et al. $(2000 ; 2005)$ agreed that the British and Scandinavian ice sheets were confluent from 29 to 25 calendar ka BP, and separated after this time. The maximum limit of the ice sheet was probably reached around 29 calendar ka BP, coinciding with a peak in clastic sedimentation on the Barra Fan (Knutz et al., 2001; Sejrup et al., 2009).

Analysis by Bradwell et al. (2008) of the Olex bathymetric dataset around the northern margin of the UK demonstrated large, curvilinear, arcuate channels and ridges, trending NE- 
SW around St Kilda, west of Orkney and Shetland, in the Moray Firth, offshore Strathmore, and flanking the western margin of the Norwegian Channel. Bradwell et al. (2008) interpreted these ridges variously as shelf-edge end moraines and subaqueous grounding-line moraines (the De Geer moraines). The majority of the negative linear features were interpreted as tunnel valleys (Ó Cofaigh, 1996), formed by subglacial meltwater flowing parallel to ice flow (Bradwell et al., 2008). The moraines occur in direct association with the major shelf edge fans (Sejrup et al., 2005; Bradwell et al., 2008), reflecting the position of a formerly extensive continental ice sheet flowing towards the Atlantic Ocean. The orientation of the associated tunnel valleys and buried mega-scale glacial lineations support an ice flow direction towards the continental shelf and confluent British and Fennoscandian ice sheets during maximum glaciation (Graham et al., 2007; Bradwell et al., 2008). Ice streams emanated from the northern British Ice Sheet, flowing eastwards and possibly coalescing with ice streams from the Fennoscandian Ice Sheet in the Witch Ground Basin (Graham et al., 2007). They were particularly notable in the Moray Firth, the Firth of Forth and in the Minch (Merritt et al., 1995; Stoker and Bradwell, 2005; Golledge and Stoker, 2006; Graham et al., 2009).

\section{The Dimlington Stadial}

The Bolders Bank Formation (Fig. 1) provides evidence for a final major advance of the Scottish and Fennoscandian ice sheets during the Dimlington Stadial. It is correlative with the Skipsea Member, dated as 21.7 calendar ka BP (Catt and Penny, 1966; Sejrup et al., 1994; Carr et al., 2006; Catt, 2007). The Bolders Bank Formation forms the south-eastward extension of the Wee Bankie Formation to the south of $56^{\circ} \mathrm{N}$, and east of $0^{\circ} \mathrm{E}$. Previous micromorphological investigation of the Bolders Bank Formation indicated genesis as a subglacial till (Carr et al., 2000), reflecting an ice sheet extending across the southern North Sea. The tectonised glaciomarine Dogger Bank Formation interfingers with, and partly overlies, the Bolders Bank Formation (Cameron et al., 1992). Carr et al. (2006) suggested that the Dogger Bank is a large moraine belt, comparable with the Main Stationary Line in Denmark. It is possible that the Dogger Bank was originally deposited ice-marginally, or in an ice-walled, ice-contact environment, trapped between the British and Fennoscandian ice sheets.

The Wee Bankie Formation occurs in the Central North Sea. It was interpreted as a subglacial till interbedded with coarse sand and gravel deposited by subglacial streams (Stoker et al., 1985). It is correlated to the Marr Bank Formation, and is contiguous with the Red Series tills in the Firth of Forth and onshore Scotland (Gatliff et al., 1994). The coeval Bolders Bank and Wee Bankie formations represent ice extending eastwards from the Midland Valley of Scotland (Carr et al., 2006). An assemblage of closely spaced small-scale ridges and channels occur on the inner shelf. Bradwell et al. (2008) interpreted these as 
smaller nearshore moraines and meltwater channels, associated with the Dimlington Stadial ice sheet.

Stewart (1991) argued that the Bosies Bank Moraine, east of the Moray Firth, represented the maximum regional position of the Dimlington Stadial ice sheet. North of $57^{\circ} \mathrm{N}$, the ridge is discontinuous, and the sediment succession is disturbed (Bradwell et al., 2008). The highly elongate bedforms in NW Scotland and Strathmore onshore and offshore suggest that ice streams were still active within the British-Irish Ice Sheet at this time, and may have been prone to periods of instability. The configuration of the Bosies Bank moraine, at the mouth of the Moray Firth, suggests that ice flow diverged to the north and south at this point (Hall and Bent, 1990; Merritt et al., 1995; Peacock and Merritt, 1997). The Bosies Bank Moraine is now thought to represent a late-stage minor stillstand or readvance of the BritishIrish Ice Sheet during the Dimlington Stadial (Graham et al., 2009).

Carr et al. (2006) argued that the Bolders Bank episode represented the advance of the British-Irish Ice Sheet after 22.7 calendar ka BP, during the Dimlington Stadial in Britain (Catt and Penny, 1966; Rose, 1985; Sejrup et al., 1994; 2000). A final restricted glaciation of Scandinavia occurred during the Tampen Stadial, where ice expanded beyond the Norwegian Channel to the North Sea Plateau. This is dated as between 21 and 18 calendar ka BP (Sejrup et al., 2009).

\section{Methodology}

Thin-section, particle-size, palynological, heavy mineral and geochemical analyses were used to identify process history and sediment provenance. Formations that are possible offshore correlatives of onshore lithostratigraphical units in eastern England were specifically targeted. Unfortunately, large spatial distances between samples were inevitable due to the lack of boreholes close to the coast and to each other. Multiple samples were taken from each lithofacies. Where possible, replicate samples of the same formation were taken from different boreholes. The number of samples available was limited, and small $(\sim 250 \mathrm{~g})$ samples were taken.

Thin section investigations were conducted according to standard techniques (Menzies and Maltman, 1992; Menzies, 2000; Hiemstra, 2007). Particle size analyses were also undertaken using standard methodologies, and a Coulter granulometer was used on the $>2$ mm fraction (Gale and Hoare, 1991; Hoey, 2004). Samples were gently disaggregated using sodium hexametaphosphate and a sonic bath. Heavy minerals were separated using density separation and the full freezing technique (Davies, in press). Over 300 non-opaque grains in the 63-120 $\mu \mathrm{m}$ and 120-250 $\mu \mathrm{m}$ size fractions were counted for each sample. They were identified using reference criteria and samples (Gale and Hoare, 1991; Mange and Maurer, 
1992; Walden, 2004). Palynomorphs were extracted using the sodium hexametaphosphate method of Riding and Kyffin-Hughes (2004).

\section{Sedimentology and Micromorphology The Swarte Bank Formation}

The Swarte Bank Formation is located in the base of buried valleys in the southern North Sea Basin, south of $55^{\circ} \mathrm{N}$. It is overlain by the Sand Hole Formation, the Hoxnian Egmond Ground Formation, the Eem Formation in the central North Sea Basin, and ultimately by Weichselian glaciogenic sediments (Cameron et al., 1992; Gatliff et al., 1994). The Swarte Bank Formation was sampled from borehole 81/52a at $40.5 \mathrm{~m}$ and $43.07 \mathrm{~m}$, and borehole $81 / 46 a$ at $17.0 \mathrm{~m}$ and $18.0 \mathrm{~m}$ (Figs 1, 2, Table 1). Borehole 81/46a is located almost directly due east of County Durham (Fig. 1), and borehole 81/52a was drilled immediately south of the Humber estuary (Table 1).

Sample $81 / 46$ a $17.0 \mathrm{~m}$ is a brown diamicton with a variable texture (Fig. 3, Table 2). The diamicton is fine-grained, the matrix is of even density and distribution, and has few clasts larger than $150 \mu \mathrm{m}$. There are rare rounded red sandstone skeleton grains, which are up to $1000 \mu \mathrm{m}$ in diameter. The diamicton includes abundant shell fragments, and it has small vugh and planar voids. It is dissected by a broken bed of manganese.

The thin section shows abundant turbate structures (van der Meer, 1993), both with and without core stones (Table 2). The turbate structures are associated with a well-developed skelsepic plasmic fabric, which is found surrounding fine skeleton grains as a thin skin. The turbates are often associated with pressure shadows. Within the diamicton these are stretched and attenuated Type III pebbles (van der Meer, 1993), often occurring in association with turbates and pressure shadows. There are numerous grain stacks and grain lineations, showing a preferred orientation of small skeleton grains (Fig. 3).

Borehole 81/52a at $40.5 \mathrm{~m}$ was taken from the conformable boundary with the Sand Hole Formation above (Table 2). It is a brown diamicton is of variable texture, and exhibits macroscopic banding (Fig. 4). Voids are present due to poor impregnation. The skeleton grains are matrix-supported but range widely in size. The finer silt and sand skeleton grains are subangular to subrounded, but generally exhibit edge rounding. Quartz, coal and sandstone grains are common. The silty clay has abundant marine microfossils, including foraminifera, radiolaria, diatoms and coccoliths. The slide exhibits abundant deformation structures, including the classic turbates with associated skelsepic plasmic fabrics and 'galaxy tails'. There are rare Type II Pebbles. Lineations of grains are common, and are associated with aligned clay particles and fine skeleton grains. Grain stacks are common (Menzies et al., 2006). 


\section{The Fisher Formation}

The Fisher Formation was sampled from boreholes 81/26, 81/29, and 81/34 (Figs. 1, 5, Table 1). Borehole $81 / 26$ is located at $58^{\circ} \mathrm{N}$, east of the Moray Firth, whilst boreholes $81 / 29$ and $81 / 34$ are located close together, approximately at $56^{\circ} \mathrm{N}$ and east of the Firth of Forth (Fig. 1). Whilst samples taken from borehole $81 / 29$ and $81 / 34$ are reasonably similar, showing fluidised bedded sands, borehole 81/26 proved a massive diamicton (Fig. 5). These boreholes have previously been logged and described (Stoker et al., 1985; Sejrup and Knudsen, 1993; Graham et al., 2007).

A thin section slide from borehole $81 / 34$ at $18.4 \mathrm{~m}$ is summarised in Table 2. Macroscopically, it is a sand with strongly deformed laminations, showing extensive dewatering and fluidisation structures (Fig. 6). There are both planar and vugh voids, induced during coring and packing, and due to poor resin impregnation in the laboratory. The slide has matrix-poor, clast-supported, well-sorted, graded sand (principally quartz) laminations. There are also some mineral and coal skeleton grains. Some laminations are composed of silty-clay laminations, and show up as a darker brown colour (Fig. 6). These finer laminations have a horizontal microfabric and a bedding-parallel masepic plasmic fabric. Normal faults cut across the fluidised sand.

Thin section samples were also taken from the Fisher Formation from borehole 81/26 at $65.4 \mathrm{~m}$ (Fig. 6, Table 2). The slide is a fine-grained dark-brown diamicton with numerous sand grains, fine rounded gravel, and occasional intraclasts. It is mostly massive although the matrix is slightly variable. There are numerous shell and coal fragments. Other lithic fragments include sandstone, basalt and other igneous pebbles. Structures present include numerous turbate structures with and without core stones, with associated grain lineations, pressure shadows, necking structures, and 'tails'. The finer skeleton grains have a strong skelsepic plasmic fabric. There are abundant well-rounded silty Type III Pebbles, grain stacks and edge-to-edge grain contacts.

\section{The Bolders Bank Formation}

The Bolders Bank Formation is coeval with the Wee Bankie Formation in the North Sea Basin north of $55^{\circ} \mathrm{N}$ and with the Skipsea Member of Yorkshire (Catt, 1991; Cameron et al., 1992; Gatliff et al., 1994). It comprises stiff diamictons of Dimlington Stadial age that blanket much of the North Sea off Lincolnshire and Yorkshire (Fig. 1). The Bolders Bank Formation was sampled from three boreholes, 81/48, 81/43, and 82/19 (Fig. 7, Table 1).

The thin-section sample from borehole 81/48 was collected at $8.9 \mathrm{~m}$ (Fig. 8). Macroscopically, the slide is a massive, reddish-brown diamicton with widely ranging grain 
sizes, numerous rounded coarse sand and fine gravel grains (Table 2). These range from shell fragments to lithic fragments of basalt, igneous and metamorphic rocks (Figs. 9A,B), limestone, sandstone, quartz, feldspar, greywacke, and numerous silty Type III rounded pebbles (Fig. 9F) with their own internal plasmic fabric. The smaller silt and fine sand grains are subangular and occasional marine microfossils were observed. There are numerous rotation structures with and without core stones within the slide (Fig. 9). Some of these are associated with grain lineations (Fig. 9F), and frequently they display 'galaxy tails'. There is a loaded and broken soft-sediment intraclast. Grain stacks and edge-to-edge grain contacts are common (Figs. 9D,E), and there are rare fractured grains, indicative of brittle deformation. The finer skeleton grains are coated with a skelsepic plasmic fabric, and a masepic plasmic fabric is ubiquitous throughout the slide.

\section{Lithological, Geochemical and Palynological Analyses}

\section{Lithological Descriptions}

The Swarte Bank Formation is a grey, upwards-fining, sandy to silty diamicton in borehole 81/52a (10YR 6/1), and a light brownish grey to greyish brown in borehole 81/46a (10YR 6/2 to 10YR 5/2). All samples reacted vigorously to $\mathrm{HCl}$, and contained fine chalk and flint gravel. Sample 81/46a 18.0 m contained Magnesian Limestone and fine quartzite gravel. No shells were found within these diamictons (Table 1).

The Fisher Formation samples are grey silty clay (10YR 6/1) to fissile, sandy diamictons, ranging in colour from dark grey (10YR 4/1) to greyish brown (10YR 5/2 to 4/2). The reaction to $\mathrm{HCl}$ is variable, from vigorous $(59.95 \mathrm{~m})$ to mild $(64.6 \mathrm{~m})$. All the samples contain rounded gravel, including Magnesian Limestone, dolerite, and quartz, a single specimen of a rounded rhomb porphyry, other porphyries, chalk, and shell fragments.

The Bolders Bank Formation is highly variable locally; the sample being a brown silty diamicton with abundant gravel (Tables 1,2). The presence of chalk in borehole 82/19 is a significant difference between the three boreholes. The borehole 82/19 diamicton is also lighter in colour and stiffer, with more clay present (Table 1).

\section{Particle Size Analysis}

Due to the small sample sizes, it was only possible to conduct particle size analysis on the $<2 \mathrm{~mm}$ fraction. The gravel lithological analysis is descriptive only. The Swarte Bank Formation has a diamict matrix and the particle-size distribution plots close to the other diamictons in the study (Fig. 10, Table 3). The Fisher Formation is dominated by silt. The sample from borehole $81 / 29$ is better sorted with no sand, whilst the samples from borehole $81 / 34$ are poorly-sorted sandy-silts. The percentage of coarse sand is low in all the samples. 
Samples from borehole 81/26 form a tight cluster on the ternary diagram, with high proportions of silt and sand, but only a small percentage of coarse sand (Fig. 10, Table 3). The particle-size distribution between samples of the Bolders Bank Formation is similar, with borehole 82/19 showing more variation than the other boreholes. It is also coarser-grained, with a higher percentage of coarse sand.

\section{Heavy Mineral Analysis}

\section{The Swarte Bank Formation}

Heavy mineral analysis was conducted on the 63-125 $\mu \mathrm{m}$ and 125-250 $\mu \mathrm{m}$ fractions (Table 4). The mineralogy of the Swarte Bank Formation includes a broad suite of minerals, which vary substantially in some cases between the samples from boreholes 81/52a and 81/46a. For example the standard deviations of garnet and biotite are 9.2 and 8.3 respectively. The majority of the other minerals have lower standard deviations between 0 and 4. The Swarte Bank Formation is characterised by high percentages of garnet (average $17.7 \%$ ), biotite (average $10.2 \%)$, muscovite (8.7 \%), epidote $(9.3 \%)$, and carbonates (6.1 $\%)$. Minerals of secondary abundance include brookite (6\%), hornblende (5.6\%), zoisite (5.9 $\%)$, chlorite (5.2\%), andalusite (5.4\%) and kyanite (3\%).

\section{The Fisher Formation}

Heavy mineral analysis of the Fisher Formation reveals an assemblage with an average $17 \%$ of garnet and high percentages of andalusite (8.8\%), kyanite $(9 \%)$, epidote $(9.7 \%)$, biotite $(9.6 \%)$, muscovite $(7.8 \%)$, and glaucophane $(5.4 \%)$. The heavy minerals of the Fisher Formation are widely spread, with a standard deviation of up to 9.4 in the case of glaucophane, 10 for epidote and 11.1 for garnet (Appendix II). Borehole 81/26 is particularly high in garnet (26.4\%), epidote (11.4\%), hornblende (8.5\%) and zoisite (5.6 \%). Micas are abundant, followed by carbonates $(5.1 \%)$, but andalusite and kyanite are less abundant than in the other samples. The Fisher Formation is richer in pyroxenes than the Swarte Bank Formation, and shows similarities to the Bolders Bank Formation (Table 4).

\section{The Bolders Bank Formation}

The heavy mineral suite from the Bolders Bank Formation is widely spread, and shows little internal consistency. Borehole $82 / 19$ is higher in garnet, but only borehole $81 / 48,8.0 \mathrm{~m}$ contains glaucophane. Hornblende is present in comparatively higher amounts in borehole $82 / 19$ (6.9 \% cf. $2.9 \%$ ). The southernmost samples are more enriched in carbonates, as would be expected due to the changing bedrock lithologies, and are significantly richer in detrital micas. 


\section{Statistical Analysis}

A principal components analysis (PCA) performed on the correlation matrix is dominated by the first three components. Components 1 and 2 together explain $67 \%$ of the variance, and the first three explain $81 \%$. Component 1 is composed of a number of variables, with silicates, amphiboles and micas controlling this axis most strongly. Component 2 is mostly controlled by epidote, and secondarily by amphiboles, oxides and phosphates. This distribution is clearly illustrated by a component loadings scatter plot (Fig. 11A). However, the scoreplot shows that the matrix mineralogy is varied, with little internal consistency. There are similarities, however, between the Swarte Bank and Fisher formations, which tend to plot distinctly from the Bolders Bank Formation. This is consistent with the scoreplot for the PCA covariance. Samples from the same borehole tend to plot most closely together, illustrating the wide regional variations between lithofacies. This is probably related to changing bedrock lithology. Cluster analysis of the heavy mineral suite supports this varied matrix mineralogy. The cluster analysis identifies similarities between the Swarte Bank and Fisher formations. The mineralogy therefore varies between samples more than within formations.

\section{Geochemistry}

Total Metals Extraction (ICP-MS) was carried out on all the samples (Table 5). The matrix geochemistry is variable between and within lithofacies associations. A correlation matrix of the variables shows that some metals are well correlated. A PCA (correlation) clearly defines two groups. The PCA is adequately explained by the first two components (a combined $94 \%$ of the variance), with Component 1 explaining the majority of the data. Component 1 is formed from several variables, namely potassium, magnesium, aluminium, and titanium. Component 2 is formed from silicon, potassium and iron (Fig. 11B). Geochemically, the Fisher Formation overlaps with the Swarte Bank Formation, with the Bolders Bank Formation being distinctly separate.

\section{Palynology}

\section{The Swarte Bank Formation}

A palynological investigation found a wide range of palynomorphs in the Swarte Bank Formation, including age-diagnostic species from the Carboniferous, Triassic, Jurassic, Cretaceous, Palaeogene and Quaternary (Table 6). Triassic miospores were recorded in low numbers in borehole 81/46 (18.0 m); these include Krauselisporites reissingeri, Ovalipollis ovalis, Riccisporites tuberculatus, Triancoraesporites ancorae and Zebrasporites 
interscriptus. These are typical of the Rhaetian (Late Triassic) (Orbell, 1973; Dunay, 1978). Marine microplankton taxa characteristic of the Early Toarcian (Early Jurassic) were observed in low numbers in borehole 81/52a (43.07 m). They include Halosphaeropsis liassica, Nannoceratopsis deflandrei subsp. senex and Nannoceratopsis sp.

There are also low numbers of characteristic Middle to Late Jurassic miospores within the Swarte Bank Formation (Table 6), including Calamospora mesozoica, Callialasporites sp., Cerebropollenites macroverrucosus, Chasmatosporites sp., Classopollis classoides, Classopollis meyeriana, Cyathidites sp., Perinopollenites elatoides and Retitriletes sp. (Riding, 2008). The dinoflagellate cyst species Oligosphaeridium patulum and Perisseiasphaeridium pannosum are indicative of input of the Kimmeridge Clay Formation (Kimmeridgian) of northern England (Riding and Thomas, 1988). Allochthonous Late Cretaceous dinoflagellate cysts were observed sporadically and occur in minor amounts in the Swarte Bank Formation, representing incorporation of the Chalk Group. Palaeogene input in borehole $81 / 46(18.0 \mathrm{~m})$ is prominent and diverse, and the presence of forms such as Deflandrea oebisfeldensis, Glaphyrocysta sp., Homotryblium sp., Hystrichosphaeridum tubiferum and Wetzeliella sp. are indicative of the Eocene. Deflandrea oebisfeldensis is indicative of latest Thanetian to Ypresian (Powell, 1992).

\section{The Fisher Formation}

The Fisher Formation contains sparse palynomorphs in borehole 81/29, but borehole $81 / 34$ is characterised by Silurian, Carboniferous, Jurassic, rare Cretaceous, Palaeogene and Quaternary palynomorphs (Table 6). The Silurian palynomorphs are relatively abundant, and include Diexallophasis denticulata and Veryhachium sp. The Cretaceous palynomorphs are present in only minimal numbers, and include rare cavate peridinioid forms characteristic of the Late Cretaceous. For example, Trithyrodinium sp. represents incorporation of the Chalk Group. Allochthonous Palaeogene dinoflagellate cysts are prominent and diverse in the Fisher Formation (borehole 81/34 at $34.0 \mathrm{~m}$ ). They include Cordosphaeridium gracile, Deflandrea oebisfeldensis, Glaphyrocysta ordinata, Homotryblium sp., Hystrichosphaeridium tubiferum, Thalassiphora pelagica and Wetzeliella sp. These forms are indicative of the Eocene (Powell, 1992). The Fisher Formation also yielded significant numbers of typical Quaternary dinoflagellate cysts, including Achomosphaera andalousiensis, Bitectatodinium tepikiense, Lingulodinium machaerophorum, Operculodinium centrocarpum, Selenopemphix quanta and Spiniferites sp. Quaternary pollen spores present include Alnus, Dryopteris, Gramineae, Pinus, Polygonium vulgare and Stereisporites.

\section{The Bolders Bank Formation}


There are significant percentages of Carboniferous spores within the Fisher Formation of borehole 81/26. Densosporites sp. and Lycospora pusilla are the most prominent taxa; these are typical of derived Carboniferous palynomorphs (Riding et al., 2003). Also present in low numbers were Radiizonates sp. and Tripartites trilinguis, characteristic of the Westphalian and the Namurian respectively (Smith and Butterworth, 1967). The Carboniferous palynomorphs therefore represent the incorporation of Namurian and Westphalian material.

The palynology of the Bolders Bank Formation is also impoverished, with borehole 81/43 $4.0 \mathrm{~m}$ containing only sparse palynomorphs. Both samples contained single specimens of the acritarch Diexallophasis denticulata which is of Silurian aspect. There are minor proportions of Carboniferous spores in all of the samples, but they are particularly prominent in borehole 82/19 (Table 6). This sample also contained Late Triassic miospores, including Krauselisporites reissingeri, Ovalipollis ovalis, Riccisporites tuberculatus, Triancoraesporites ancorae and Zebrasporites interscriptus. These forms are diagnostic of the Rhaetian Stage (Orbell, 1973; Dunay, 1978). Early Jurassic (Early Toarcian) marine microplankton are also present and include Halosphaeropsis liassica, Nannoceratopsis deflandrei subsp. senex and Nannoceratopsis sp. This association is typical of the Early Toarcian oceanic anoxic event and this interpretation is supported by the presence of abundant levels of amorphous organic material in the Bolders Bank Formation (Bucefalo Palliani and Riding, 2003). Borehole 81/48 $8.0 \mathrm{~m}$ is also relatively rich in Early Cretaceous dinoflagellate cysts, and yielded Batioladinium sp., Cassiculosphaeridia sp., Cribroperidinium gigas, Cyclonephelium distinctum, Gochteodinia villosa, Gochteodinia virgula, Phoberocysta neocomica and Rotosphaeropsis thula (Riding, 2008). This association is indicative of the JurassicCretaceous boundary and Phoberocysta neocomica is indicative of earliest Cretaceous (Davey, 1982).

\section{Discussion}

\section{Process and Provenance Interpretations}

The Swarte Bank Formation: Process

The Swarte Bank Formation was interpreted as an Elsterian (MIS 12) subglacial till, correlated with the chalky Lowestoft Till in Norfolk (Scourse et al., 1998) and recording the first invasion of ice into the southern North Sea (Cameron et al., 1992). However the evidence for earlier glaciations during MIS 16 in East Anglia has been debated (Lee et al., 2004; Preece et al., 2009). The Swarte Bank Formation fills an array of tunnel valleys up to $12 \mathrm{~km}$ wide and $450 \mathrm{~m}$ deep, cut into the Pleistocene deltaic deposits (Rhine-Thames) and pre-Pleistocene strata (Cameron et al., 1987). It has been correlated with the chalky Lowestoft Till in Norfolk (Scourse et al., 1998). The Swarte Bank Formation was sampled 
here in boreholes $81 / 46 \mathrm{a}$ at 17.0 and $18.0 \mathrm{~m}$, and in boreholes $81 / 52 \mathrm{~A}$ at $43.07 \mathrm{~m}$, which were previously described by Balson and Jeffery (1991), Cameron et al. (1992) and Scourse et al. (1998). The Swarte Bank Formation in these boreholes is a grey sandy diamicton with fine gravel, no shells, and a vigorous reaction to $\mathrm{HCl}$ (Table 1, Fig. 2).

This study used thin section analysis to further investigate the processes of deposition for the Swarte Bank Formation in borehole 81/46A (17.0 m). The grey-brown, wellconsolidated diamict composition, angular small skeleton grains and ductile deformation structures such as turbates, skelsepic plasmic fabrics and pressure shadows indicate a derivation as a subglacial till (Carr, 2001). The reworked marine fossils and Type III pebbles indicate cannibalisation of pre-existing sediments, and are a common feature of subglacial tills (Carr, 2001; Carr et al., 2006). There are few large skeleton grains, as the diamicton is derived from reworked marine sediments (Table 2). The lack of large skeleton grains and homogeneity of grain size results in fewer turbates and other structures (Hart et al., 2004). Grain lineations associated with masepic plasmic fabrics indicating shear are common (Hiemstra and Rijsdijk, 2003) Grain stacks are present in small numbers, indicating a highstrain environment (Menzies et al., 2006). This work therefore supports previous interpretations of the Swarte Bank Formation as a subglacial till deposited by a grounded ice sheet (Menzies, 2000; van der Meer et al., 2003; Menzies et al., 2006).

\section{The Swarte Bank Formation: Provenance}

Palynological analysis of the Swarte Bank Formation provided sensitive provenance information for the sediments in the North Sea Basin. Borehole 81/46A contained rare Late Triassic miospores, probably derived from northern England. Borehole 81/52a (43.07 m) contained rare Early Jurassic marine microplankton taxa, typical of the Early Toarcian anoxic oceanic event. Middle and Late Jurassic palynomorphs are consistently present, indicating input of the Kimmeridge Clay Formation (Riding and Thomas, 1988; Riding, 2008), which crops out in northern England and the Moray Firth. Both samples contained rare palynomorphs characteristic of the Late Cretaceous, representing incorporation of the Chalk Group, located to the north and east of the study site. Sparse allochthonous Palaeogene dinoflagellate cysts were observed in the Swarte Bank Formation, indicative of the latest Thanetian to Ypresian interval. This Eocene material is present in significant numbers in borehole $81 / 46 \mathrm{~A}$, and represents the input of local material from the east of the borehole location. Although borehole $81 / 46 \mathrm{~A}$ rests on Permian bedrock, there is little palynomorph expression of this, but these strata are typically poor in palynomorphs (Riding, 2007).

The heavy mineral suite of the Swarte Bank Formation indicates a derivation from NE Scotland. Firstly, the ferromagnesian minerals olivine and clinopyroxenes are from an ultramafic to mafic source. The most likely sources are the Carboniferous volcanic rocks 
(phyric basalts) and related high-level intrusive rocks (dolerites and basalts), Upper Silurian to Lower Devonian volcanic rocks, and the Palaeogene volcanic and high-level intrusive rocks that crop out from the Midland Valley southwards (Cameron and Stephenson, 1985; Trewin, 2002).

The metamorphic suite of heavy minerals (tourmaline, garnet, sillimanite, andalusite, kyanite, staurolite and chloritoid) is consistent with the source terrane including a significant amount of upper greenschist to upper amphibolite facies and regionally metamorphosed pelitic metasedimentary rocks, and is similar to the Devensian tills from County Durham (Davies et al., 2009). An association of garnet, staurolite and chloritoid is indicative of Stonehavian-type metamorphism. The development of this association is strongly controlled by the whole-rock chemistry of the pelitic mudstone, and is therefore only developed in specific areas. Chloritoid is a distinctive mineral only found in the Scottish Highlands (Stephenson and Gould, 1995). Stonehavian-type metamorphism is limited to a small area to the east of Stonehaven close to the Highland Boundary Fault (Trewin, 2002). A second metamorphic suite, consisting of garnet, andalusite and kyanite, is typical of Buchan-type metamorphism, from the Buchan coast near Aberdeen. The metamorphic minerals within the Swarte Bank Formation therefore represent an input from the Dalradian Supergroup along the coast of NE Scotland.

In summary, the Swarte Bank Formation is interpreted as a subglacial till, containing moderately abundant Carboniferous, Cretaceous, Palaeogene and Quaternary palynomorphs. The heavy mineral assemblage is characterised by high percentages of garnet, biotite, muscovite and epidote. Statistical analysis of the heavy mineral suite and matrix geochemistry was unable to distinguish this formation from the Fisher Formation (Fig. 11). The geochemistry, biostratigraphy and petrology all indicate a provenance from eastern Scotland near the Highland Boundary Fault, with some input from the Central North Sea Basin.

\section{The Fisher Formation: Process}

There are two facies of the Fisher Formation, with subglacial and glaciomarine facies both being attributed to a major glacial episode in MIS 6/8. During this time there was ice in the Inner Moray Firth (north of $58^{\circ} 30^{\prime} \mathrm{N}$ ) resulting in a more northerly diamictic facies of the Fisher Formation, and an ice-proximal environment in the outer Moray Firth, where a large subaqueous fan was built out from a tidewater glacier, forming a series of overlapping fans. During the northward retreat of the glacier, a series of stillstands and re-advances occurred, forming large subaqueous moraines. These form significant topographic highs on the sea bed (Andrews et al., 1990). The $40.0 \mathrm{~m}$ thick Fisher Formation diamicton in borehole 81/26 has previously been identified as a MIS 6 subglacial till (Sejrup et al., 1987), whilst the more 
southerly boreholes $81 / 34$ and $81 / 29$ exhibit the glaciomarine sand facies of the Fisher Formation.

Micromorphological analysis of the thin section from borehole 81/26 at $65.4 \mathrm{~m}$ (Fig. 6) indicates formation as a subglacial till on the basis of several lines of evidence. These are the consolidated matrix of the diamict; numerous structures indicative of ductile deformation, such as turbate structures with and without core stones, with trailing tails of smaller skeleton grains, a skelsepic plasmic fabric, and rounded, silty type III pebbles, indicative of cannibalisation and the incorporation of pre-existing sediments (Menzies, 2000; Menzies et al., 2006); associated grain stacks and grain lineations (Hiemstra and Rijsdijk, 2003; van der Meer et al., 2003; Menzies et al., 2006); fragmented marine bivalves suggesting reworking of marine sediments, and the presence of far-travelled igneous lithic fragments.

Thin section analysis of borehole 81/34 (Fig. 6) shows a strongly deformed sand, with vestiges of primary, graded bedding. This sand is interpreted as a subaqueously deposited sediment that has suffered extensive soft-sediment deformation and a polyphase history of deposition and deformation. The first phase is the deposition of sand laminae. Compaction and compression by the overlying sediments, possibly by ice-push or down-slope movement, resulted in dewatering and liquefaction of sediments (Phillips et al., 2007). As porewater pressure decreased after dewatering, brittle faulting occurred within the fluidised sand in the final phase of deformation. This sediment was deposited subaqueously, possibly in a glaciomarine environment, although there is little direct evidence of this within this particular slide.

\section{The Fisher Formation: Provenance}

The samples from borehole 81/34 yielded rare Silurian acritarchs (Table 6). These are light in colour, so they cannot have been derived from the cleaved Silurian slates of the Southern Uplands, as the thermal alteration of these rocks is high and all palynomorphs are dark brown to black in colour. The only possible British source is the Midland Valley of Scotland, south of the Firth of Forth, which was not significantly metamorphosed. A source from the North Sea Basin is not likely due to the extremely deep burial of Palaeozoic strata. The assemblages are similar to those from the Early Silurian of the Ringerike area, Oslo, Norway (Smelror, 1987). The Eocene input is probably local; there are no obvious sources in onshore eastern England. The association of the freshwater alga Pediastrum sp. and Quaternary pollen and dinoflagellate cysts suggests the reworking of Neogene or Quaternary sediments from the North Sea Basin.

The more northerly borehole $81 / 26$ yielded a significant number of characteristic Carboniferous (Westphalian) spores, suggestive of a source in the Midland Valley of Scotland. It also produced a large number of Quaternary spores and a single, rounded clast 
of Scandinavian rhomb porphyry, probably reworked from sediments on the North Sea floor. The heavy mineral suite of the Fisher Formation supports derivation from the Grampian Highlands, with both the characteristic staurolite-garnet-chloritoid and garnet-andalusitekyanite assemblages represented. Epidote is also present, suggesting the input of the epidote-amphibolite facies of the Grampian Highlands (Trewin, 2002).

The succession in borehole 81/26 may represent the Swarte Bank Formation. Although there is clearly an influence from the Dalradian Supergroup of Scotland, the comparatively low percentages of andalusite and kyanite suggest a weaker input of Buchan metamorphism. Alternatively, the high percentage of the ultra-stable garnet and monazite phases may reflect reworking and diagenesis, with the removal of less stable minerals. These samples are the only ones containing piemontite, which occurs in low-grade regionally metamorphosed schists and gneisses, such as those from the Dalradian Supergroup (Mange and Maurer, 1992). The Fisher Formation therefore includes traces of both Buchan- and Stonehaviantype metamorphism and epidote-amphibolite facies, and was probably derived from the Grampian Highlands and the NE coast of Scotland.

In summary, the Fisher Formation is interpreted as a subglacial till in boreholes to the north near the Moray Firth (borehole 81/26), and as a glaciomarine diamicton in the more southerly boreholes east of the Firth of Forth (boreholes 81/29 and 81/34). This glaciomarine sediment is a strongly deformed and distorted sand that has retained some primary bedding structures. Mineralogical analyses show that it varies strongly between boreholes, probably due to large intervening distances and varying bedrock lithologies. The abundant metals, however, form a tightly-clustered group with similarities to the Swarte Bank Formation (Fig. 11B). Pale Silurian palynomorphs are present, and there are low numbers of Cretaceous forms. The Silurian palynomorphs indicate derivation from the Midland Valley of Scotland. The heavy mineral assemblage indicates a source from the Scottish Highlands, close to the Highland Boundary Fault.

\section{The Bolders Bank Formation: Process}

The Bolders Bank Formation directly overlies the Chalk Group in offshore eastern England. It was previously described as a diamicton with a chaotic to poorly ordered internal seismic reflector configuration. In borehole samples it is typically a reddish to greyish brown, stiff, massive diamicton with occasional distinct, arenaceous layering and deformation structures (Cameron et al., 1992; Gatliff et al., 1994; Cameron and Holmes, 1999). It contains abundant chalk and flint pebbles derived from eastern England, the gravel content decreasing eastwards. In general, it is less than $5 \mathrm{~m}$ thick. It has been interpreted as a composite of subglacial and supraglacial deposits (Cameron et al., 1992), and as a 
subglacial till (Carr et al., 2006). Cameron et al. (1992) correlated the Bolders Bank Formation with the Devensian tills of Hunstanton and Holderness.

The Bolders Bank Formation was sampled from boreholes 81/48, 81/43 and 82/19 (Table 1). The samples all contained brown, silty to clay-rich diamictons, with granite, Carboniferous Limestone, sandstone, coal, Magnesian Limestone, flint, chalk and dolerite (Figs 1, 7, Table 1). They contain fragments of marine bivalve shells, but yielded rare Silurian acritarchs, low numbers of Early Jurassic marine microplankton taxa, characteristic Middle and Late Jurassic palynomorphs and abundant Early Cretaceous palynomorphs (Table 6).

The thin section taken from borehole $81 / 48$ at $8.9 \mathrm{~m}$ (Fig. 8) is characterised by its consolidated diamictic texture, large, far-travelled, igneous lithic fragments, rare marine palynomorphs and numerous rounded Type III pebbles (van der Meer et al., 2003).

Microstructures include edge-to-edge grain contacts, crushed grains, numerous turbates, a well-developed skelsepic/lattisepic plasmic fabric, grain lineations and grain stacks (Fig. 8, Table 2). These features indicate genesis as a subglacial till subjected to shearing and rotational pressures in a confining, water-saturated environment (Menzies et al., 2006), and support the interpretation of Carr et al. (2006) as a subglacial till. Turbates form in response to simple shear under high pore water pressure (Hart et al., 2004). The skelsepic plasmic fabric coating fine skeleton grains forms when clay platelets are aligned in response to rotating skeleton grains (van der Meer, 1993; Menzies, 2000). Edge-to-edge contacts with individual skeleton grains are indicative of a high-strain environment (Menzies et al., 2006). Grain lineations have been suggested to form under high-strain environments in response to simple shear (Menzies, 2000). The presence of soft-sediment intraclasts suggests cannibalisation of pre-existing sediments, whilst its deformation adds further support to a high-strain environment deforming with high pore-water pressure. This slide therefore exhibits features typical of sediments deposited beneath a grounded ice sheet.

\section{The Bolders Bank Formation; Provenance}

The Silurian palynomorphs recovered were derived from the Midland Valley of Scotland (see above). For the Carboniferous and Late Triassic palynomorphs, the most likely source is northern England, possibly including the Midland Valley for the Carboniferous material. The Early Jurassic palynomorphs were probably sourced from the Tweed Valley. The Middle and Late Jurassic forms were probably derived from northern England or the Moray Firth. The incorporation of the Upper Jurassic Kimmeridge Clay Formation is clear in borehole 81/48, supported by the presence of abundant amorphous organic material. The heavy mineral suite of the Bolders Bank Formation similarly exhibits phases and assemblages typical and diagnostic of the Grampian Highlands, Dalradian, and NE coast of Scotland (see above). 
In summary, the Bolders Bank Formation is interpreted as a subglacial till based on the outcrops offshore of eastern England. It contains detrital material sourced from NE Scotland, the Midland Valley of Scotland, northern England, and possibly the Moray Firth.

\section{Onshore Correlatives}

The Middle Pleistocene

The complex glaciogenic sediments of north Norfolk provide strong evidence of an MIS 12 glaciation (Hamblin et al., 2005; Pawley et al., 2008; Preece et al., 2009). The Lowestoft and Swarte Bank formations both indicate an extensive British, Scottish-sourced ice sheet (Fish and Whiteman, 2001). Provenance work herein indicates that the Swarte Bank Formation was deposited by an ice sheet with accumulation areas in the NE Scottish Highlands, showing input from the Dalradian Supergroup and the Midland Valley of Scotland. These sediments infill tunnel valleys in the North Sea Basin, and represent a sediment deposited at the ice-bed interface. The Lowestoft Formation is a silty, clayey, chalk-rich diamicton with Mesozoic mudstone clasts, reflecting glacial transport from Scotland, across the North Sea, Lincolnshire and Yorkshire (Lee et al., 2002; Rose et al., 2002).

Terrestrial evidence for a Scottish-sourced MIS 6 glaciation in Britain is limited. The glaciomarine Fisher Formation provides evidence of a Scottish ice sheet calving into the North Sea during the Middle Pleistocene; however, the chronostratigraphy remains poor. Again, the NE Scottish Highlands are an important ice-accumulation area. The Cromer Ridge in Norfolk has been attributed to MIS 6 (Hamblin et al., 2005), but recent OSL dating has suggested that these sediments are of MIS 12 age (Pawley et al., 2008). Straw (1979) argued that a Saalian glaciation in MIS 6 or 8 covered much of Lincolnshire, and extended southwards to Norfolk and Suffolk, but the age constraints are poor. Nonetheless, the succession at Welton-le-Wold has often been regarded as likely to include deposits of postAnglian, pre-Devensian glacial sediments (Straw, 1979; Straw, 1983; Lewis, 1999; Straw, 2005). Glaciomarine sediments in County Durham, attributed largely to a Scottish glaciation, have been attributed to a pre-MIS 6 glaciation, and could possibly be correlative with the Fisher Formation (Davies et al., in press).

The MIS 6 glaciation in the Netherlands and Germany is widely acknowledged to have been particularly extensive, with icesheets extending southwards and eastwards from Norway (Ehlers et al., 1984; Baumann et al., 1995; Eissmann, 2002; Houmark-Nielsen and Gibbard, 2004). This Saalian glaciation was presumably coalescent with the British and Irish Ice Sheet. This is supported by the presence of tunnel valleys offshore (Huuse and LykkeAndersen, 2000; Praeg, 2003). An extensive MIS 6 continental glaciation implies that the 
MIS 6 glaciation was also prominent in Britain, and that the evidence has largely been eradicated by subsequent glaciation during the Devensian.

\section{The Dimlington Stadial and the North Sea Lobe}

The Weichselian maximum limit was reached at around 29 calendar ka (Sejrup et al., 2009) (Fig. 12A). At the Last Glacial Maximum, the Fennoscandian Ice Sheet reached the Norwegian shelf edge along its entire length, from the mouth of the Norwegian Channel to North Cape, Finnmark, in northernmost Norway (Mangerud, 2004). At 26.8 calendar ka BP, the British and Fennoscandian ice sheets were still coalescent in the North Sea Basin, with separation at around 25 calendar ka, possibly as a result of sea level rise (Svendsen et al., 2004; Sejrup et al., 2005; 2009).

The offshore Last Glacial Maximum record can be compared with onshore tills at Whitburn Bay, County Durham (Davies et al., 2009). These complex, ice-marginal sediments incorporate numerous sand and gravel-filled subglacial channels, and are dissected by hydrofractures and pipe structures. The lower subglacial till, the Blackhall Member, was deposited during Flow Phase I (Fig. 12A) by ice flowing to the east through the Tyne Gap (Davies et al., 2009). Flow Phase I probably occurred during an early configuration of the British-Irish Ice Sheet, but still during the Late Devensian.

An upper subglacial till, the Horden Member, was deposited during the Last Glacial Maximum, Flow Phase II (Fig. 12B), and extends a short distance inland (Smith and Francis, 1967). The margin is marked by moraines and ice-contact slopes (Smith and Francis, 1967). It forms part of an ice-marginal, terrestrial, warm-based glacial landsystem. The Horden Member was derived from ice in NE Scotland, the Grampians, and the Cheviots, which flowed down the east coast of England as the North Sea Lobe. It is coeval with the Skipsea Member of Yorkshire (Eyles et al., 1994; Davies et al., 2009), and shares critical provenance indicators with this unit (Davies et al., 2009). The western edge of the Skipsea Member delineates the onshore Dimlington limit around the Yorkshire Wolds (Ehlers and Wingfield, 1991; Carr, 1999; Carr et al., 2000).

Micromorphological analysis of the Bolders Bank Formation demonstrates that it is characteristic of a subglacially-derived till. These features include a well-developed masepic/skelsepic plasmic fabric, rotational structures with associated grain lineations, and a compacted, diamict matrix (van der Meer et al., 2003; Menzies et al., 2006; Hiemstra, 2007). Further detailed sedimentological and petrological analysis would be required to distinguish if there are two tills offshore; the two onshore tills are similar and may have both been grouped into the Bolders Bank Formation. The North Sea Lobe may also have removed much of the Blackhall Member offshore, and incorporated it into the Horden Member. Based on similar provenance indicators, such as NE Scottish metamorphic detrital material, and Midland 
Valley and northern England erratics, (Davies et al., 2009), genesis and inferred ice flow direction, the Bolders Bank Formation is correlative with the Horden Member. This reflects an east coast ice lobe flowing southwards through eastern Britain.

The North Sea Lobe (Fig. 12B; Flow Phase II) was a major feature of the Late Weichselian British-Irish Ice Sheet along the east coast of England. It was sourced in the Scottish Highlands, and combined ice flow from the Southern Uplands with ice flowing eastwards out of the Midland Valley of Scotland. Further to the south, it coalesced with the Tweed ice stream (Everest et al., 2005; Mitchell, 2008), as evidenced by the distribution and orientation of drumlins and glacial lineations (Raistrick, 1931). It deposited a subglacial till from Northumberland southwards, which consistently shows directional evidence of onshore flow (Beaumont, 1967; Eyles et al., 1982; Teasdale and Hughes, 1999). The offshore lateral margins represent the limits of the Bolders Bank Formation (Catt, 1991; Ehlers and Wingfield, 1991).

Although Sejrup et al. (2005) and Carr et al. (2006) have suggested that the British-Irish Ice Sheet and the Fennoscandian Ice Sheet were not coalescent in the North Sea Basin during the Dimlington Stadial, it is difficult to explain the shape of the North Sea Lobe and its tendency to flow in a SE, onshore direction (Fig. 12B) without buttressing from Fennoscandian ice immediately to the east. It flowed onshore in County Durham, Yorkshire and in The Wash, damming glacial lakes, whilst flowing to the east to form a piedmont lobe in the southern North Sea. Peacock and Merritt (1997) and Svendsen et al. (2004) argued for coalescence of the British and Fennoscandian ice sheets in the North Sea until 20 calendar ka BP. However, Sejrup et al. (1994) and Carr et al. (2006) argued for separate ice sheets and the deposition of the Skipsea Member by the North Sea Lobe during a later, post-Last Glacial Maximum phase of restricted glaciation (i.e. after 22.4 calendar ka BP). This date corresponds with the restricted Tampen Stadial reached by the Fennoscandian Ice Sheet in the North Sea Basin (Sejrup et al., 1987; 1994; 2005), where it reached the edge of the Norwegian Channel, which supports ice-free conditions in the central North Sea Basin during the existence of the North Sea Lobe. The Marr Bank Formation also provides evidence of glaciomarine conditions at 21.7 calendar yr BP (Holmes, 1977; Stoker et al., 1985). However, early coalescence during the main Last Glacial Maximum phase, around 26 calendar ka BP (Sejrup et al., 2005), provides a mechanism for the southward trajectory of the Late Weichselian North Sea Lobe operating down the eastern coast of Britain. The North Sea Lobe continued to exist during the Dimlington Stadial, but with open-marine conditions in the North Sea (Fig. 12C). The chronostratigraphy of the various ice streams operating during the Last Glacial Maximum and the Dimlington Stadial is poor, so it is difficult to precisely date these. 
The arrival of the North Sea Lobe along eastern Britain trapped a considerable amount of meltwater inland, resulting in a series of large proglacial lakes. These included Glacial Lake Wear and Glacial Lake Humber (Smith and Francis, 1967; Clark et al., 2004b; Murton et al., in press)). OSL dates on these glaciolacustrine sediments indicates that the North Sea Lobe was still in existence during the Last Glacial Maximum until Heinrich Event 1 (Bateman et al., 2008; Murton et al., in press).

\section{Ice flow pathways}

Previous workers have provided little indication of the provenance of glaciogenic sediments in the North Sea, and process interpretations have been confined to limited sedimentological evaluations from boreholes and seismostratigraphical data (Andrews et al., 1990; Sejrup et al., 1991; Cameron et al., 1992; Merritt et al., 1995; Sejup et al., 2000; 2005; Graham et al., 2007; Bradwell et al., 2008; Golledge et al., 2008). Provenance has been relatively vaguely attributed, for example, to 'the Scottish Mainland' (Andrews et al., 1990) or 'Scandinavia' (Gatliff et al., 1994).

Statistical analysis shows that many of the sediments sampled herein have similar heavy mineral assemblages, and thus had similar ice source areas and ice flow trajectories, which is to be expected in low-relief areas. The ICP-MS data (Fig. 11) falls into two groups. The Bolders Bank Formation is highly distinctive, while the Swarte Bank and Fisher formations form a second group, with the Swarte Bank data being dispersed and showing little matrix homogeneity. In both the heavy mineral and matrix geochemistry, the variations are closely related to sample location. The Fisher Formation demonstrates considerable interformational variability. For example, borehole 81/26, in the north, was deposited sub-glacially (Fig. 6). However, further to the south, in borehole 81/34, the Fisher Formation records a glaciomarine environment. This suggests that the ice sheet that deposited the Fisher Formation was of limited extent, extending north and east from the Moray Firth.

The various glaciogenic lithofacies share several characteristics, and show evidence of being sourced from the Grampian Highlands and the NE coast of Scotland during MIS 12, 6 and 2 (Fig. 12A). The multi-proxy provenance analysis herein shows that ice flow pathways operated in the Moray Firth, Firth of Forth, Midland Valley and the Tweed Valley throughout the Quaternary, with characteristic northern English erratic material.

The palynofloras and kerogen from the eight samples analysed for palynomorphs proved relatively similar, with assemblages diagnostic of a derivation from northern Britain, including the western margin of the North Sea. However, some subtle differences between the samples can be discerned. For example, the Swarte Bank Formation yielded significantly higher percentages of Silurian palynomorphs. In order to entrain Silurian palynomorphs, the 
ice sheet would have to have been generated in the Scottish Highlands and then deflected eastwards along the Firth of Forth (possibly by the Southern Uplands fault scarp), before flowing southwards towards the North Sea Basin.

All the samples show strong evidence for a derivation from northern Britain. Here, a Grampian and Highlands, NE Scotland (Aberdeen) and NW North Sea origin for these formations is indicated, with inputs from northern England. The ice sheets originated in northern Britain, before entraining material from the Midland Valley of Scotland, and material passing out through the Moray Firth and Firth of Forth (Fig. 12A). From here, they spread eastwards and southwards into the North Sea Basin. Geomorphological mapping indicates that, at their maximum and certainly during shelf-edge glaciation, these ice sheets extended northwards to the continental shelf (Bradwell et al., 2008; Graham et al., 2009), eastwards to meet Scandinavian ice in the North Sea Basin (Graham et al., 2007), and southwards towards the Wash and north Norfolk (Hamblin et al., 2005; Pawley et al., 2006; Pawley et al., 2008; Phillips et al., 2008).

This has been a successful pilot study for investigating the genesis and provenance of various Quaternary sediments in the North Sea Basin. However, the formations identified by the British Geological Survey contain many complex facies, and these vary laterally due to changing bedrock. Distinctions between lateral equivalents like the Wee Bankie and Bolders Bank formations are considerable simplifications of units which include multiple lateral variants. Similarly, identifying land-sea correlations is difficult due to differing diagenesis and varying matrix compositions between onshore and offshore tills. However, conclusions can be drawn regarding the behaviour of the ice sheets in Britain during the Quaternary, and particularly detailed observations can be made regarding the Dimlington Stadial ice sheet. This study has underlined the link between the Bolders Bank Formation and the Horden Member, both of which exhibit very similar provenance characteristics.

\section{Conclusions}

A systematic thin section study integrated with multi-proxy provenance analysis of various North Sea Quaternary sediments has provided substantial new evidence supporting a subglacial genesis for the Swarte Bank, Fisher and Bolders Bank formations. The two facies of the Fisher Formation indicate that probably during MIS 6, there was ice in the Moray Firth, but that further south, the Fisher Formation in borehole 81/34 was deposited in a glaciomarine environment. This indicates that ice was calving from the coast of Scotland into a marine embayment in MIS 6 if the dating constraints are accurate.

The principal conclusion of this study is that the glacigenic sediments in the western North Sea Basin show evidence of repeated ice flow pathways, with ice originating from the 
Grampian Highlands and delivering a clear Dalradian Supergroup signal into the North Sea Basin. Thin section analysis of glaciogenic sediments supports interpretations of a grounded ice sheet within the North Sea Basin at various times from the Middle Pleistocene onwards. The heterogeneity of the Quaternary sediments within the North Sea Basin require a more in depth and fundamental reassessment to fully chronicle their provenance and process histories. However, the NE coast of the Scottish Highlands has been shown herein to have been an important ice-accumulation area throughout the Quaternary, with ice repeatedly flowing through the Midland Valley of Scotland and the Southern Uplands.

During the Weichselian, the eastern-central part of the last British-Irish Ice Sheet received ice from multiple sources, and changing ice divides and ice-accumulation areas led to the dominance of different ice lobes and ice streams at different times. The North Sea Lobe, sourced in the Highlands of Scotland, first overwhelmed the area. It flowed eastwards through the Midland Valley, and southwards around the Southern Uplands. Here it coalesced with or overwhelmed Lake District and Southern Uplands ice. The ice was diverted down the Tyne Gap by Lake District and Irish Sea ice. Eastern County Durham received ice mostly from western Scotland, and ice from the Lake District did not factor here.

After recession of the Tyne Gap ice, an ice lobe advanced down the eastern coast of Britain, ultimately reaching Norfolk, possibly as late as Heinrich Event 1. It trapped vast quantities of meltwater between its flanks and the higher ground onshore, resulting in numerous proglacial lakes. Abundant fluvioglacial meltwater deposited sands and gravels, which were overridden by later glaciation of east coast ice. This North Sea Lobe was sourced in the Scottish Highlands, and its sediments bear Scottish and Cheviot erratics. It coalesced with the Tweed ice stream, which it deflected southwards, most likely due to the presence of a Scandinavian ice sheet in the North Sea.

\section{Acknowledgements}

This work formed part of the PhD studentship of BJD. BJD would like to thank DHR, DRB, and CÓC of Durham University for help, guidance and support. The work was funded by the Hatfield Trust, Durham University, and the Department of Geography of Durham University. Thin sections were made by David Sales of the Department of Earth Sciences, Durham University. The authors thank Simon Carr, David Evans and Alistair Graham for helpful and constructive comments, and the British Geological Survey for access to the cores. James B. Riding publishes with the approval of the Executive Director, British Geological Survey (NERC).

\section{References}


Andrews, I. J., Long, D., Richards, P. C., Thomson, A. R., Brown, S., Cheshire, J. A., and McCormac, M. 1990. The Geology of the Moray Firth. United Kingdom Offshore Regional Report. Memoir of the British Geological Survey. HMSO: London.

Balson, P. S., and Jeffery, D. H. 1991. The Glacial Sequence of the southern North Sea. In: Glacial Deposits in Great Britain and Ireland. (J. Ehlers, P. Gibbard, and J. Rose, Eds.). A.A. Balkema: Rotterdam; 245-253.

Bateman, M. D., Buckland, P. C., Chase, B., Frederick, C. D., and Gaunt, G. D. 2008. The Late-Devensian proglacial Lake Humber: new evidence from littoral deposits at Ferrybridge, Yorkshire, England. Boreas 37: 195-210.

Baumann, K.-H., Lackschewitz, K. S., Mangerud, J., Spielhagen, R. F., Wolfwelling, T. C. W., Henrich, R., and Kassens, H. 1995. Reflection of Scandinavian Ice Sheet Fluctuations in Norwegian Sea Sediments during the Past 150,000 Years. Quaternary Research 43: 185-197.

Beaumont, P. 1967. The glacial deposits of eastern Durham. Unpublished PhD Thesis: Department of Geography, Durham University.

Bowen, D. Q., Phillips, F. M., McCabe, A. M., Knutz, P. C., and Sykes, G. A. 2002. New data for the Last Glacial Maximum in Great Britain and Ireland. Quaternary Science Reviews 21: 89-101.

Bradwell, T., Stoker, M. S., Golledge, N. R., Wilson, C. K., Merritt, J. W., Long, D., Everest, J. D., Hestvik, O. B., Stevenson, A. G., Hubbard, A. L., Finlayson, A. G., and Mathers, H. E. 2008. The northern sector of the last British Ice Sheet: Maximum extent and demise. Earth-Science Reviews 88: 207-226.

Bucefalo Palliani, R., and Riding, J. B. 2003. Biostratigraphy, provincialism and evolution of European Early Jurassic (Pliensbachian to early Toarcian) dinoflagellate cysts. Palynology 27: 179-214.

Cameron, I. B., and Stephenson, D. 1985. British Regional Geology No. 5: the Midland Valley of Scotland. Memoir of the British Geological Survey. HMSO: London.

Cameron, T., and Holmes, R. 1999. The Continental Shelf. In: A Revised Correlation of Quaternary Deposits in the British Isles. Geological Society Special Report. Vol. 23. (D. Q. Bowen, Ed.). Geological Society: London; 125-139.

Cameron, T. D. J., Crosby, A., Balson, P. S., Jeffery, D. H., Lott, G. K., Bulat, J., and
Harrison, D. J. 1992. United Kingdom Offshore Regional Report: The Geology of the Southern North Sea. HMSO: London.

Cameron, T. D. J., Stoker, M. S., and Long, D. 1987. The history of Quaternary sedimentation in the UK sector of the North Sea Basin. Journal of the Geological Society, London 144: 43-58.

Carr, S. J. 2001. Micromorphological criteria for distinguishing subglacial and glacimarine sediments: evidence from a contemporary tidewater glacier, Spitsbergen. Quaternary International 86: 71-79.

Carr, S. J., Haflidason, H., and Sejrup, H. P. 2000. Micromorphological evidence supporting Late Weichselian glaciation of the northern North Sea. Boreas 29: 315328.

Carr, S. J., Holmes, R., van der Meer, J. J. M., and Rose, J. 2006. The Last Glacial Maximum in the North Sea: Micromorphological evidence of extensive glaciation. Journal of Quaternary Science 21: 131-153.

Catt, J. A. 1991. Late Devensian glacial deposits and glaciations in eastern England and the adjoining offshore region. In: Glacial deposits in Great Britain and Ireland. (J. Ehlers, P. L. Gibbard, and J. Rose, Eds.). A.A. Balkema: Rotterdam; 6168.

Catt, J. A. 2007. The Pleistocene glaciations of eastern Yorkshire: a review. Proceedings of the Yorkshire Geological Society 56: 177208.

Catt, J. A., and Penny, L. F. 1966. The Pleistocene deposits of Holderness, East Yorkshire. Proceedings of the Yorkshire Geological Society 35: 375-420.

Clark, C. D., Gibbard, P. L., and Rose, J. 2004a. Pleistocene glacial limits in England, Scotland and Wales. In: Quaternary Glaciations - Extent and Chronology. Part 1 - Europe. (J. Ehlers, and P. L. Gibbard, Eds.). Elsevier: Amsterdam; 47-82.

Clark, C. D., Evans, D. J. A., Khatwa, A., Bradwell, T., Jordan, C. J., Marsh, S. H., Mitchell, W. A., and Bateman, M. D. 2004b. Map and GIS database of glacial landforms and features related to the last British Ice Sheet. Boreas 33: 359-375.

Davey, R. J. 1982. The stratigraphic distribution of dinocysts in the Portlandian (latest Jurassic) to Barremian (Early Cretaceous) of northwest Europe. American Association of Stratigraphic Palynologists Contributions Series 5B: 49-81.

Davies, B. J. in press. Heavy Mineral Analysis: Methods. In: Clast Analysis. Technical 
Guide. (D. R. Bridgland, Ed.). Quaternary Research Association: London;

Davies, B. J., Roberts, D. H., Bridgland, D. R., Ó Cofaigh, C., and Riding, J. B. in press. Timing and depositional environments of the Scandinavian glaciation of northeast England: New evidence from Warren House Gill, County Durham. Quaternary Science Reviews.

Davies, B. J., Roberts, D. H., Bridgland, D. R., Ó Cofaigh, C., Riding, J. B., Phillips, E. R., and Teasdale, D. A. 2009. Interlobate ice sheet dynamics during the Last Glacial Maximum at Whitburn Bay, County Durham, England. Boreas 38: 555-575.

Dunay, R. E. 1978. Late Triassic and Early Jurassic subsurface palynostratigraphy in northwestern Europe. Palinological número extraordinario 1: 355-365.

Ehlers, J., Meyer, K.-D., and Stephan, H.-J. 1984. The Pre-Weichselian glaciations of North-West Europe. Quaternary Science Reviews 3: 1-40.

Ehlers, J., and Wingfield, R. T. R. 1991. The extension of the Late Weichselian / Late Devensian ice sheets in the North Sea Basin. Journal of Quaternary Science 6: 313-326.

Eissmann, L. 2002. Quaternary Geology of eastern Germany (Saxony, Saxon-Anhalt, South Brandenburg, Thüringia), type area of the Elsterian and Saalian stages in Europe. Quaternary Science Reviews 21: 1275-1346.

Evans, D., Owen, L., and Roberts, D. H. 1995. Stratigraphy and sedimentology of Devensian (Dimlington Stadial) glacial deposits, east Yorkshire, England. Journal of Quaternary Science 10: 241-265.

Everest, J., Bradwell, T., and Golledge, N. 2005. Subglacial landforms of the Tweed palaeo-ice stream. Scottish Geographical Journal 121: 163-173.

Eyles, N., McCabe, A. M., and Bowen, D. Q. 1994. The stratigraphic and sedimentological significance of Late Devensian Ice Sheet surging in Holderness, Yorkshire, U.K. Quaternary Science Reviews 13: 727-759.

Eyles, N., Sladen, J. A., and Gilroy, S. 1982. A depositional model for stratigraphic complexes and facies superposition in lodgement tills. Boreas 11: 317-333.

Fish, P. R., and Whiteman, C. A. 2001. Chalk micropalaeontology and the provenancing of Middle Pleistocene Lowestoft Formation till in eastern England. Earth Surface Processes and Landforms 26: 953-970.

Gale, S. J., and Hoare, P. G. 1991. Quaternary Sediments: Petrographic methods for the study of unlithified rocks. John Wiley \& Sons: New York.

Gatliff, R. W., Richards, P. C., Smith, K., Graham, C. C., McCormac, M., Smith, N. J. P., Long, D., Cameron, T. D. J., Evans, D., Stevenson, A. G., Bulat, J., and Ritchie, J. D. 1994. The Geology of the Central North Sea. United Kingdom Offshore Regional Report. British Geological Survey. HMSO: London.

Golledge, N. R., Finlayson, A., Bradwell, T., and Everest, J. D. 2008. The last glaciation of Shetland, North Atlantic. Geografiska Annaler Series A - Physical Geography 90A: 37-53.

Golledge, N. R., and Stoker, M. S. 2006. A palaeo-ice stream of the British ice sheet in eastern Scotland. Boreas 35: 231-243.

Graham, A. G. C., Lonergan, L., and Stoker, M. S. 2007. Evidence for Late Pleistocene ice stream activity in the Witch Ground Basin, central North Sea, from 3D seismic reflection data. Quaternary Science Reviews 26: 627-643.

Graham, A. G. C., Lonergan, L., and Stoker, M. S. 2009. Seafloor glacial features reveal the extent and decay of the last British Ice Sheet, east of Scotland. Journal of Quaternary Science 24: 117-138.

Hall, A. D., and Bent, A. J. 1990. The limits of the last British Ice Sheet in northern Scotland and the adjacent shelf. Quaternary Newsletter 61: 2-12.

Hamblin, R. J. O., Moorlock, B. S. P., Rose, J., Lee, J. R., Riding, J. B., Booth, S. J., and Pawley, S. M. 2005. Revised PreDevensian glacial stratigraphy in Norfolk, England, based on mapping and till provenance. Netherlands Journal of Geosciences-Geologie En Mijnbouw 84: 77-85.

Hart, J. K., Khatwa, A., and Sammonds, P. 2004. The effect of grain texture on the occurrence of microstructural properties in subglacial till. Quaternary Science Reviews 23: 2501-2512.

Hiemstra, J. F. 2007. Micromorphology of Glacial Sediments. In: Encyclopedia of Quaternary Science. (S. A. Elias, Ed.). Elsevier: Amsterdam, London; 945-954.

Hiemstra, J. F., and Rijsdijk, K. F. 2003. Observing artificially induced strain: implications for subglacial deformation. Journal of Quaternary Science 18: 373-383.

Hoey, T. B. 2004. The size of sedimentary particles. In: A practical guide to the study of glacial sediments. (D. J. A. Evans, and D. I. Benn, Eds.). Arnold: London; 51-76.

Holmes, R. 1977. Quaternary deposits of the central North Sea, 5. The Quaternary 
geology of the UK sector of the North Sea between $56^{\circ}$ and $58^{\circ} \mathrm{N}$ : Institute of Geological Sciences;

Houmark-Nielsen, M., and Gibbard, P. L. 2004. The Pleistocene of Denmark: A review of stratigraphy and glaciation history. In: Developments in Quaternary Science. Elsevier; 35-46.

Huuse, M., and Lykke-Andersen, H. 2000. Overdeepened Quaternary valleys in the eastern Danish North Sea: morphology and origin. Quaternary Science Reviews 19: 1233-1253.

Knutz, P. C., Austin, W. E. N., and Jones, E. J. W. 2001. Millennial-scale depositional cycles related to British Ice Sheet variability and North Atlantic paleocirculation since 45 kyr BP, Barra Fan, UK margin. Paleoceanography 16: 53-64.

Lee, J. R., Rose, J., Hamblin, R. J. O., and Moorlock, B. S. P. 2004. Dating the earliest lowland glaciation of eastern England: a pre-MIS 12 early Middle Pleistocene Happisburgh glaciation. Quaternary Science Reviews 23: 1551-1566.

Lee, J. R., Rose, J., Riding, J. B., Moorlock, B. S. P., and Hamblin, R. J. O. 2002. Testing the case for a Middle Pleistocene Scandinavian glaciation in Eastern England: evidence for a Scottish ice source for tills within the Corton Formation of East Anglia, UK. Boreas 31: 345-355.

Lewis, S. G. 1999. Eastern England. In: A revised correlation of Quaternary deposits in the British Isles. (D. Q. Bowen, Ed.). Geological Society Special Report no. 23: London; 10-27.

Mange, M. A., and Maurer, H. F. W. 1992. Heavy Minerals in Colour. Chapman and Hall: London.

Mangerud, J. 2004. Ice sheet limits in Norway and on the Norwegian continental shelf. In: Quaternary Glaciations - extent and chronology. (J. Ehlers, and P. Gibbard, Eds.). Elsevier; 271-294.

Menzies, J. 2000. Micromorphological analyses of microfabrics and microstructures indicative of deformation processes in glacial sediments. In: Deformation of Glacial Materials. Geological Society Special Publication 176. (A. J. Maltman, A. J. Hubbard, and M. J. Hambrey, Eds.). Geological Society of London: London; 245-257.

Menzies, J., and Maltman, A. J. 1992. Microstructures in diamictons - evidence of subglacial bed conditions. Geomorphology 6: $27-40$.

Menzies, J., van der Meer, J. J. M., and Rose, J. 2006. Till-as a glacial "tectomict", its internal architecture, and the development of a "typing" method for till differentiation. Geomorphology 75: 172-200.

Merritt, J. W., Auton, C. A., and Firth, C. R. 1995. Ice-proximal glaciomarine sedimentation and sea-level change in the Inverness area, Scotland: A review of the deglaciation of a major ice stream of the British Late Devensian ice sheet. Quaternary Science Reviews 14: 289-329.

Mitchell, W. A. 2008. Quaternary geology of part of the Kale Water catchment, Western Cheviot Hills, southern Scotland. Scottish Journal of Geology 44: 51-63.

Murton, D. K., Pawley, S. M., and Murton, J. B. in press. Sedimentology and luminescence ages of Glacial Lake Humber deposits in the central Vale of York. Proceedings of the Geologists' Association: doi:10.1016/j.pgeola.2009.09.001.

Ó Cofaigh, C. 1996. Tunnel Valley Genesis. Progress in Physical Geography 20: 1-19.

Orbell, G. 1973. Palynology of the British Rhaeto-Liassic. Bulletin of the Geological Survey 44: 1-44.

Pawley, S. M., Bailey, R. M., Rose, J., Moorlock, B. S. P., Hamblin, R. J. O., Booth, S. J., and Lee, J. R. 2008. Age limits on Middle Pleistocene glacial sediments from OSL dating, north Norfolk, UK. Quaternary Science Reviews 27: 13631377.

Pawley, S. M., Candy, I., and Booth, S. J. 2006. The Late Devensian terminal moraine ridge at Garret Hill, Stiffkey valley, north Norfolk, England. Proceedings of the Yorkshire Geological Society 56: 31-39.

Peacock, J. D., and Merritt, J. W. 1997. Glacigenic rafting at Castle Hill, Gardenstown, and its significance for the glacial history of northern Banffshire, Scotland. Journal of Quaternary Science 12: 283-294.

Peltier, W. R., and Fairbanks, R. G. 2006. Global glacial ice volume and Last Glacial Maximum duration from an extended Barbados sea level record. Quaternary Science Reviews 25: 3322-3337.

Phillips, E., Lee, J. R., and Burke, H. 2008. Progressive proglacial to subglacial deformation and syntectonic sedimentation at the margins of the Mid-Pleistocene British lce Sheet: evidence from north Norfolk, UK. Quaternary Science Reviews 27: 1848-1871.

Phillips, E., Merritt, J., Auton, C. A., and Golledge, N. 2007. Microstructures in subglacial and proglacial sediments: understanding faults, folds and fabrics, and the influence of water on the style of 
deformation. Quaternary Science Reviews 26: $1499-1528$.

Powell, A. J. 1992. Dinoflagellate cysts of the Tertiary System. In: A Stratigraphic Index of Dinoflagellate Cysts. (A. J. Powell, Ed.). Chapman and Hall: London; 155-251.

Praeg, D. 2003. Seismic imaging of MidPleistocene tunnel-valleys in the North Sea Basin-high resolution from low frequencies. Journal of Applied Geophysics 53: 273-298.

Preece, R. C., Parfitt, S. A., Coope, G. R., Penkman, K. E. H., Ponel, P., and Whittaker, J. E. 2009. Biostratigraphic and aminostratigraphic constraints on the age of the Middle Pleistocene glacial succession in north Norfolk, UK. Journal of Quaternary Science 24: 557-580.

Raistrick, A. 1931. Glaciation. Proceedings of the Geologists' Association 42: 281-291.

Riding, J. B. 2007. A Palynological investigation of diamictons and tills from northeast England. Internal Report IR/07/021R. British Geological Survey Internal Report: Nottingham.

Riding, J. B. 2008. A Palynological investigation of tills from the North Sea Basin. Internal Report IR/08/025. British Geological Survey: Nottingham.

Riding, J. B., and Kyffin-Hughes, J. E. 2004. A review of the laboratory preparation of palynomorphs with a description of an effective non-acid technique. Revista Brasileira de Paleontologia 7: 13-44.

Riding, J. B., Rose, J., and Booth, S. J. 2003. Allochthonous and indigenous palynomorphs from the Devensian of the Warham Borehole, Stiffkey, north Norfolk, England: evidence for sediment provenance. Proceedings of the Yorkshire Geological Society 54: 223-235.

Riding, J. B., and Thomas, J. E. 1988. Dinoflagellate cyst stratigraphy of the Kimmeridge Clay (Upper Jurassic) from the Dorset coast, southern England. Palynology 12: $65-88$.

Rose, J. 1985. The Dimlington Stadial / Dimlington Chronozone: a proposal for naming the main glacial episode of the Late Devensian in Britain. Boreas 14: 225-230.

Rose, J., Candy, I., Moorlock, B. S. P., Wilkins, H., Lee, J. A., Hamblin, R. J. O., Lee, J. R., Riding, J. B., and Morigi, A. N. 2002. Early and early Middle Pleistocene river, coastal and neotectonic processes, southeast Norfolk, England. Proceedings of the Geologists' Association 113: 47-67.

Scourse, J. D., Ansari, M. H., Wingfield, R. T. R., Harland, R., and Balson, P. S. 1998. A middle Pleistocene shallow marine interglacial sequence, Inner Silver Pit, southern North Sea: Pollen and dinoflagellate cyst stratigraphy and sealevel history. Quaternary Science Reviews 17: 871-900.

Sejrup, H. P., Aarseth, I., Ellingsen, K. L., Reither, E., and Jansen, E. 1987.

Quaternary stratigraphy of the Fladen area, central North Sea: a multidisciplinary study. Journal of Quaternary Science 2: 35-58.

Sejrup, H. P., Aarseth, I., and Haflidason, H. 1991. The Quaternary succession in the northern North Sea. Marine Geology 101: 103-111.

Sejrup, H. P., Haflidason, N., Aarseth, I., King, E., Forsberg, C. F., Long, D., and Rokoengen, K. 1994. Late Weichselian glaciation of the northern North Sea. Boreas 23: 1-13.

Sejrup, H. P., Hjelstuen, B. O., Torbjorn Dahlgren, K. I., Haflidason, H., Kuijpers, A., Nygard, A., Praeg, D., Stoker, M. S., and Vorren, T. O. 2005. Pleistocene glacial history of the NW European continental margin. Marine and Petroleum Geology 22: 1111-1129.

Sejrup, H. P., and Knudsen, K. L. 1993. Palaeoenvironments and correlations of interglacial sediments in the North Sea. Boreas 22: 223-235.

Sejrup, H. P., Larsen, E., Landvik, J., King, E. L., Haflidason, H., and Nesje, A. 2000. Quaternary glaciations in southern Fennoscandia: evidence from southwestern Norway and the northern North Sea region. Quaternary Science Reviews 19: 667-685.

Sejrup, H. P., Nygård, A., Hall, A. M., and Haflidason, H. 2009. Middle and Late Weichselian (Devensian) glaciation history of south-western Norway, North Sea and eastern UK. Quaternary Science Reviews 28: $370-380$.

Smelror, M. 1987. Early Silurian acritarchs and prasinophycean algae from the Rinerike District, Olso region (Norway). Review of Palaeobotany and Palynology 52: 137-159.

Smith, A. H. V., and Butterworth, M. A. 1967. Miospores in the coal seams of the Carboniferous of Great Britain. Special Papers in Palaeontology 1: 324.

Smith, D. B., and Francis, E. A. 1967. Geology of the Country between Durham and West Hartlepool (Explanation of one-inch Geological Sheet 27, New Series). Her Majesty's Stationary Office: London.

Stephenson, D., and Gould, D. 1995. British Regional Geology: The Grampian Highlands. Fourth Edition. Memoir of the British Geological Survey. Her Majesty's Stationery Office: London. 
Stewart, F. S. 1991. A reconstruction of the eastern margin of the Late Weichselian Ice Sheet in Northern Britain. Unpublished PhD Thesis. University of Edinburgh;

Stoker, M. S., and Bradwell, T. 2005. The Minch palaeo-ice stream, NW sector of the British-Irish Ice Sheet. Journal of the Geological Society 162: 425-428.

Stoker, M. S., Long, D., and Fyfe, J. A. 1985. A revised Quaternary stratigraphy for the central North Sea. British Geological Survey Report 17 (2). HMSO: London.

Straw, A. 1979. The Geomorphological Significance of the Wolstonian Glaciation of Eastern England. Transactions of the Institute of British Geographers 4: 540-549.

Straw, A. 1983. Pre-Devensian glaciation of Lincolnshire (eastern England) and adjacent areas. Quaternary Science Reviews 2: 239-260.

Straw, A. 2005. Glacial and pre-glacial deposits at Welton-le-Wold, Lincolnshire. The Studio Publishing Services Ltd.

Svendsen, J. I., Alesanderson, H., Astakhov, V. I., Demidov, I., Dowdeswell, J. A., Funder, S., Gataullin, V., Henricksen, M. Hjort, C., Houmark-Nielsen, M., Hubberten, H. W., Ingólfsson, O., Jakobsson, M., Kjær, K., Larsen, E., Lokrantz, H., Lunkka, J. P., Lyså, A., Mangerud, J., Matiouchkov, A., Murray, A., Moller, P., Niessen, F., Nikolskaya, O., Polyak, L., Saarnisto, M., Siegert, C., Siegert, M. J., Spielhagen, R., and Stein, R. 2004. Late Quaternary ice sheet history of northern Eurasia. Quaternary Science Reviews 23: 12291271.

Teasdale, D. A., and Hughes, D. B. 1999. The glacial history of north-east England. In: The Quaternary of north-east England. Field Guide. (D. R. Bridgland, B. P. Horton, and J. B. Innes, Eds.). Quaternary Research Association: London; 10-17.

Trewin, N. H. 2002. The Geology of Scotland. Fourth Edition. The Geological Society of London: London.

van der Meer, J. J. M. 1993. Microscopic Evidence of Subglacial Deformation. Quaternary Science Reviews 16: 827-831. van der Meer, J. J. M., Menzies, J., and Rose, J. 2003. Subglacial till: the deforming glacier bed. Quaternary Science Reviews 22: 1659-1685.

Walden, J. S. 2004. Particle Lithology (or mineral and geochemical analysis). In: $A$ practical guide to the study of glacial sediments. (D. J. A. Evans, and D. I. Benn, Eds.). Arnold: London; 145-180. 